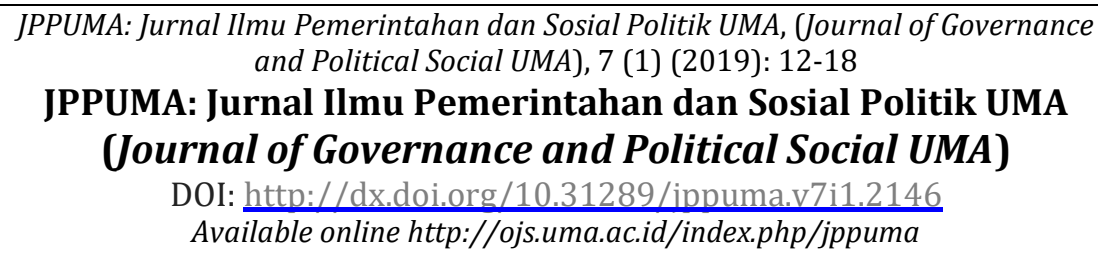

JPPUMA: Jurnal Ilmu Pemerintahan dan Sosial Politik UMA

(Journal of Governance and Political Social UMA)

DOI: http://dx.doi.org/10.31289/ippuma.v7i1.2146

Available online http://ojs.uma.ac.id/index.php/jppuma

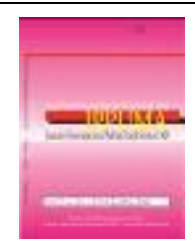

\title{
Pengaruh Koordinasi terhadap Efektivitas Penanggulangan HIV/AIDS Kabupaten Sumedang
}

\section{The Influence of Coordination on The Effectiveness of HIV/AIDS Prevention in Sumedang Regency}

\author{
Irma Hermayanty* \& Dhesti Widya Nurhasanah Ningrum
}

Program Studi Ilmu Administrasi Negara, Sekolah Tinggi Ilmu Administrasi Sebelas April,

Sumedang, Indonesia

Diterima: Desember 2018; Disetujui: Februari 2019; Dipublish: Juni 2019

\begin{abstract}
ABSTRAK.
Penelitian ini bertujuan untuk mengetahui seberapa besar pengaruh koordinasi terhadap efektivitas penanggulangan HIV/AIDS di Kabupaten Sumedang. Metode penelitian menggunakan metode deskriptif analisis dan teknik pengumpulan data berupa teknik studi kepustakaan dan teknik studi lapangan. Populasi dalam penelitian ini adalah petugas komisi penanggulangan HIV/AIDS dan Kader Warga Peduli AIDS sebanyak 19 orang. Teknik pengambilan sampel menggunakan sampling jenuh yaitu seluruh populasi dijadikan sampel penelitian. Teknik analisis yang digunakan untuk menguji hipotesis penelitian adalah dengan Perhitungan Porsentase, Uji Koefisiensi Spearman Rank, Uji Signifikansi, dan Uji Koefisien Determinasi. Hasil penelitian dan perhitungan statistik yang dilakukan terhadap hipotesis yang diajukan, dapat disimpulkan bahwa terdapat pegaruh koordinasi komisi penanggulangan AIDS dengan kader warga peduli AIDS terhadap efektivitas pencapaian program penanggulangan HIV/AIDS di Kabupaten Sumedang sebesar 47,2\%

Kata Kunci: Koordinasi, Efektivitas pencapaian program
\end{abstract}

\section{ABSTRACT.}

This study aims to determine how much influence coordination of the effectiveness of HIV/AIDS prevention in Sumedang District. This research method use is Descriptive analysis and the data collection techniques were conducted using literature study techniques and field study techniques. Population in this research are HIV/AIDS prevention commision officer and people of AIDS Citizen Cadres in totally 19 peoples. To test the research hypothesis used analysis techniques, which are by Percentage Calculation, Spearman Rank Coefficient Test, Significance Test, and Determinarion Coefficient Test. The result of research and statistical calculation on the proposed hypotheesis, can be concluded that there is any influence coordinating between HIV/AIDS prevention commission officer with AIDS Citizen Cadres on the effectiveness of HIV/AIDS prevention program achievement in Sumedang by 47,2\%.

Keywords: Coordination, Effectiveness of Program Achievement

How to Cite: Hermayanty, I \& Ningrum, D.W.N (2019). Pengaruh Koordinasi Terdahap Efektivitas Penanggulangan HIV/AIDS Kabupaten Sumedang. JPPUMA: Jurnal Ilmu Pemerintahan dan Sosial Politik UMA (Journal of Governance and Political Social UMA), 7 (1): 12-18

*Corresponding author:

E-mail: irmaharyanty79@gmail.com
ISSN 2549-1660 (Print)

ISSN 2550-1305 (Online) 


\section{PENDAHULUAN}

HIV atau Human Immunodeficency Virus adalah virus yang menurunkan kekebalan tubuh manusia dan termasuk golongan retrovirus yang terutama ditemukan di dalam cairan tubuh, seperti darah, cairan mani, cairaan vagina dan air susu ibu. AIDS atau Acquired Immune Deficiency Syndrom adalah sekumpulan gejala penyakit yang timbul karena turunnya kekbalan tubuh. AIDS disebabkan oleh infeksi HIV. Akibat menurunnya kekebalan tubuh timbul berbagai penyakit oportunistik seperti TBC, kandidiasis, berbagai radang pada kulit, paru, saluran pencernaan, otak dan kanker (Komisi Penanggulangan AIDS Nasional).

Setiap tahunnya jumlah Orang Dengan HIV/AIDS (ODHA) mengalami peningkatan termasuk di Provinsi Jawa Barat khususnya di Kabupaten Sumedang. Berdasarkan data yang diperoleh dari Komisi Penanggulangan AIDS (KPA) Kabupaten Sumedang, selama kurun waktu tiga tahun terakhir jumlah ODHA di Kabupaten Sumedang sebagai berikut: Tahun 2015 ODHA berjumlah 36 orang, Tahun 2016 ODHA berjumlah 40 orang, dan Tahun 2017 (sampai dengan 31 mei 2017) ODHA berjumlah 45 orang (Profil Komisi Penanggulang AIDS Kabupaten Sumedang 2017).

Kabupaten Sumedang melakukan beberapa program penanggulangan HIV/AIDS. Program tersebut terdiri dari 6 (enam) program yaitu: Komunikasi perubahan perilaku (KPP); Pemakaian kondom 100\% didaerah beresiko; Layanan klinik infeksi menular seksual (IMS); Pengurangan dampak buruk penggunaan narkoba; Konseling dan testing sukarela; dan Perawatan, dukungan dan pengobatan

Agar angka ODHA mengalami penurunan di tahun-tahun kedepannya, maka pelaksanaan program-program tersebut harus dilakukan secara efektif. Dimana yang dimaksud dengan efektif yaitu bahwa program tersebut dapat terukur seberapa besar capaian sasaran dan tujuan yang telah ditentukan sebelumnya. Ketika hasil capaian telah sesuai atau melebihi sasaran dan tujuan yang ditentukan maka capaian program penanggulangan HIV/AIDS dapat dikatakan telah efektif.

Salah satu faktor pendukung dalam efektivitas pencapaian program penanggulangan HIV/AIDS yaitu perlunya koordinasi yang baik antara petugas KPA dengan Kader Warga Peduli AIDS (WPA), termasuk di Kabupetan Sumedang. Koordinasi merupakan bagian yang tidak tepisahkan dari suatu kegiatan administrasi didalam suatu organisasi. Menurut Iskandar (2013) koordinasi adalah proses penyatupaduan saran-saran dan kegiatan-kegiatan dari unitunit yang terpisah (bagian dari bidang fungsional) dari sesuatu organisasi secara efisien. Fungsi organisasi ini sedemikian pentingnya, apalagi bila organisasi harus berjalan sebagai suatu sistem, sebagai suatu kesatuan yang bulat dari bagian-bagian (sub sistem) yang saling berhubungan, saling menunjang, dan saling bergantung. Oleh karena itu terdapat pengaruh koordinasi antara KPA dengan Kader WPA terhadap efektivitas pencapaian program penanggulangan HIV/AIDS di Kabupaten Sumedang.

\section{METODE PENELITIAN}

Pada penelitian ini, bentuk metode yang akan digunakan adalah bentuk pendekatan penelitian deskriptif analisis, sehubungan data yang akan dipelajari adalah data yang diambil dari populasi tersebut. Yaitu agar ditemukan kejadian-kejadian relatif, distribusi dan hubungan-hubungan antar komponen. Populasi pada penelitian ini adalah petugas Komisi Penanggulangan AIDS Kabupaten Sumedang dan Kader Warga Peduli AIDS sebanyak 19 orang yang terdiri dari petugas Komisi Penanggulangan AIDS sebanyak 10 orang, dan dari Kader Warga Peduli AIDS sebanyak 9 orang. Sehingga teknik sampling yang digunakan adalah teknik sampling jenuh, dimana semua populasi penelitian dijadikan sampel penelitian.

Adapun teknik analisis data yang digunakan terdiri dari: Uji Validitas Instrumen menggunakan Pearson Product Moment. Pada pengujian ini dilakukan pengujian validitas terhadap masing-masing butir instrumen penelitian dari masing-masing variabel yang diteliti; Uji Reliabilitas Instrumen menggunakan Alpha Cronbach. Pengujian dilakukan untuk mengukur tingkat reliabilitas dari instrumen penelitian setiap variabel yang diteliti; Perhitungan Porsentase. Tujuan dari pengujian ini adalah untuk mengetahui nilai porsentase dari masing-masing dimensi yang 
diteliti pada setiap variabel; Uji Korelasi menggunakan Spearman Rank. Dalam pengujian ini untuk mencari ada atau tidaknya korelasi diantara kedua variabel yang diteliti; Uji Signifikansi menggunakan $Z_{\text {hitung. }}$ Perhitungan ini bertujuan untuk mencari tingkat korelasi diantara kedua variabel yang diteliti; dan Uji Koefisien Determinasi. Pengujian ini dilakukan untuk mencari besaran pengaruh diantara kedua variabel yang diteliti.

\section{HASIL DAN PEMBAHASAN Koordinasi}

Koordinasi menurut Safii'e (2010) adalah "Sinkronisasi yang teratur dari usahausaha untuk menciptakan pengaturan waktu dan terpimpin, dalam hal pelaksanaan yang harmonis dan bersatu untuk menghasilkan tujuan yang telah ditetapkan". Koordinasi

\begin{tabular}{|c|c|c|c|c|}
\hline $\begin{array}{l}\text { No } \\
\text { Item }\end{array}$ & Indikator & $\begin{array}{l}\text { Jumlah } \\
\text { Kumulatif }\end{array}$ & $\begin{array}{l}\text { Persentase } \\
(\%)\end{array}$ & Kriteria \\
\hline 1 & Memiliki tujuan pekerjaan yang jelas & 69 & 72,63 & Baik \\
\hline 2 & Memahami tujuan pekerjaan & 70 & 73,68 & Baik \\
\hline 3 & Memiliki prosedur kerja & 69 & 72,63 & Baik \\
\hline 4 & Memahami prosedur kerja & 67 & 70,53 & Baik \\
\hline 5 & Bekerja sesuai prosedur kerja & 66 & 69,47 & Baik \\
\hline 6 & Memiliki pengetahuan dalam pekerjaan & 62 & 65,26 & $\begin{array}{l}\text { Cukup } \\
\text { Baik }\end{array}$ \\
\hline 7 & $\begin{array}{l}\text { Memiliki keterampilan dalam menyelesaikan } \\
\text { pekerjaan }\end{array}$ & 64 & 67,37 & $\begin{array}{l}\text { Cukup } \\
\text { Baik }\end{array}$ \\
\hline 8 & $\begin{array}{l}\text { Memliki sarana dan prasarana kerja yang } \\
\text { lengkap }\end{array}$ & 55 & 57,89 & $\begin{array}{l}\text { Cukup } \\
\text { Baik }\end{array}$ \\
\hline 9 & $\begin{array}{l}\text { Mampu memanfaatkan saran dan prasarana } \\
\text { kerja }\end{array}$ & 57 & 60,00 & $\begin{array}{l}\text { Cukup } \\
\text { Baik }\end{array}$ \\
\hline 10 & Lingkungan kerja nyaman & 59 & 62,11 & $\begin{array}{l}\text { Cukup } \\
\text { Baik }\end{array}$ \\
\hline 11 & Lingkungan kerja aman & 65 & 68,42 & Baik \\
\hline 12 & Adanya kejelasan didalam pembagian kerja & 64 & 67,37 & $\begin{array}{l}\text { Cukup } \\
\text { Baik }\end{array}$ \\
\hline 13 & Menaati pembagian tugas & 66 & 69,47 & Baik \\
\hline 14 & Adanya keserasian kegiatan dalam bekerja & 63 & 66,32 & $\begin{array}{l}\text { Cukup } \\
\text { Baik }\end{array}$ \\
\hline 15 & $\begin{array}{l}\text { Adanya saling menukar informasi mengenai } \\
\text { pekerjaan diantara pegawai }\end{array}$ & 62 & 65,26 & $\begin{array}{l}\text { Cukup } \\
\text { Baik }\end{array}$ \\
\hline 16 & $\begin{array}{l}\text { Adanya pemberian masukan berupa } \\
\text { ide/gagasan dalam bekerja }\end{array}$ & 55 & 57,89 & $\begin{array}{l}\text { Cukup } \\
\text { Baik }\end{array}$ \\
\hline 17 & $\begin{array}{l}\text { Adanya kesedian saling membantu dalam } \\
\text { bekerja diantara pegawai }\end{array}$ & 48 & 50,53 & $\begin{array}{l}\text { Kurang } \\
\text { Baik }\end{array}$ \\
\hline 18 & $\begin{array}{l}\text { Adanya penggunaan sumber daya - sumber } \\
\text { daya dalam pelaksanaan pekerjaan }\end{array}$ & 58 & 61,05 & $\begin{array}{l}\text { Cukup } \\
\text { Baik }\end{array}$ \\
\hline 19 & $\begin{array}{l}\text { Adanya peningkatan dalam efisiensi pencapaian } \\
\text { tugas }\end{array}$ & 56 & 58,95 & $\begin{array}{l}\text { Cukup } \\
\text { Baik }\end{array}$ \\
\hline 20 & peningkatan dalam & 63 & 66,32 & Cukup \\
\hline
\end{tabular}
sendiri. berikut ini:

Tabel 1

Kategori Hasil Penilaian Koordinasi Per Indikator

menempati peranan penting karena begitu banyak kita temui tumpang-tindihnya pekerjaan yang disebabkan tidak adanya koordinasi, kendati keseluruhannya itu dapat disinkronkan, diatur demi tujuan dan kepentingan bersama. Keuntungan adanya koordinasi sebenarnya adalah terciptanya sinergi yaitu diperolehnya hasil kerja sama yang lebih besar dari jumlah hasil individual kalau masing-masing individu bekerja sendiri-

Hasil perhitungan menunjukkan bahwa pencapaian hasil variabel koordinasi sebesar $65,16 \%$ yang artinya koordinasi tersebut berada di kategori Cukup Baik. Hasil perhitungan tersebut dapat dilihat pada tabel 


\begin{tabular}{llll}
\hline \multicolumn{2}{c}{ pencapaian tugas } & \multicolumn{2}{c}{ Baik } \\
\hline Jumlah & 1238 & 1303,16 & \\
\hline Rata-Rata & & 65,16 & Cukup \\
\end{tabular}

Sumber: Hasil Penelitian 2018

Berdasarkan tabel di atas diketahui bahwa beberapa indikator penelitian dari koordinasi yang memiliki hasil perhitungan yang berada di kategori cukup baik bahkan ada yang berada pada kategori kurang baik seperti kurangnya pengetahuan yang dimiliki dalam bekerja, kurangnya keterampilan dalam menyelesaikan pekerjaan, sarana dan prasarana kerja yang tidak lengkap, ketidakmampuan memanfaatkan sarana dan prasarana kerja, kurangnya kesetediaan saling membantu dalam bekerja dan lainnya.

Untuk mencapai tujuan dari program kerja ataupun organisasi diperlukan koordinasi yang baik antar pegawai, karena koordinasi menurut Handoko (2003) dianggap sebagai "Proses pengintegrasian tujuan-tujuan dan kegiatan-kegiatan pada satuan-satuan yang terpisah (departemen atau bidang-bidang fungsional) suatu organisasi untuk mencapai tujuan organisasi secara efisien". Dengan demikian, koordinasi akan menciptakan sinergi dalam arti terciptanya perpaduan usaha dari berbagai orang, unit, atau organisasi yang menghasilkan output yang lebih besar dibanding dengan jumlah output masing-masing orang, unit atau organisasi bila mereka bekerja sendiri-sendiri atau tanpa koordinasi.

Adapun sebab-sebab timbulnya koordinasi menurut Handayaningrat (1996) dibagi tiga sebagai berikut: 1)Sejumlah dan kompleksnya fungsi dan kegiatan yang secara khusus dilakukan oleh berbagai-bagai unit atau perorangan; 2)Bertambahnya pengkhususan-pengkhususan dari pada berbagai kegiatan hingga memperbessar struktur organisasi; dan 3)Dengan semakin kompleksnya dan besarnya struktur organisasi menambah pula masalah koordinasi. Demikian pula azas dari pada rentang pengendalian (span of control) termasuk pula dalam masalah koordinasi

Adapun unsur-unsur yang terkandung dalam usaha koordinasi menurut Suganda (2002) meliputi: 1)Unit-unit atau organisasiorganisasi, adalah kelompok-kelompok kerja di dalam suatu organisasi yang tentunya mempunyai fungsi yang berbeda. Organisasi- organisasi tersebut dapat berupa instansi pemerintah, organisasi swasta, ataupun badan usaha. Fungsinya mungkin sama, mungkin juga berbeda; 2)Sumber-sumber (potensi). Sumber-sumber atau potensi yang ada pada unit-unit suatu organisasi atau pada organisasi-organisasi adalah tenaga kerja, keterampilan dan pengetahuan personilnya, teknologi, anggaran, serta fasilitas kerja lainnya; 3)Kesatupaduan, artinya terdapat pertautan atau hubungan di antara sesamanya sehingga mewujudkan suatu integritas atau suatu kesatuan yang kompak.; 4)Gerak kegiatan, adalah segala daya upaya, segala sesuatu tindakan yang dikerjakan oleh pejabat-pejabat maupun kelompok kerja dalam melakukan tugasnya; 5)Keserasian, yaitu adanya urutan-urutan pengerjaan sesuatu yang tersusun secara logis, sistematis, atau dilakukan dalam waktu yang bersamaan akan tetapi tidak menimbulkan duplikasi (pengulangan), pertumbuhan maupun pertentangan; 6)Arah yang sama (sasaran). Dalam hal ini sebagai pedoman ialah sasaran yang sudah ditetapkan. Segala potensi itu diarahkan ke sasaran yang satu itu juga, sehingga tidak terjadi penyimpangan. Disinilah sebenarnya fungsi administrasi itu beroperasi mulai dari penetapan sasaran sampai dengan penilaian dan pengawasan

Dengan semakin kompleksnya dan besarnya struktur organisasi menambah pula masalah koordinasi. Demikian pula azas dari pada rentang pengendalian (span of control) termasuk pula dalam masalah koordinasi.

\section{Efektivitas Penanggulangan HIV/AIDS Kabupaten Sumedang}

Pada umumnya efektivitas sering dihubungkan dengan efisiensi dalam pencapaian tujuan organisasi. Padahal suatu tujuan atau saran yang telah tercapai sesuai dengan rencana dapat dikatakan efektif, tetapi belum tentu efisien. Walaupun terjadi suatu peningkatan efektivitas dalam suatu organisasi maka belum tentu itu efisien. Jelasnya, jika sasaran atau tujuan telah tercapai sesuai dengan yang direncanakan sebelumnya dapat dikatakan efektif. 
Jadi bila suatu pekerjaan itu tidak selesai sesuai waktu yang telah ditentukan, maka dapat dikatakan tidak efektif. Efektivitas merupakan gambaran tingkat keberhasilan atau keunggulan dalam mencapai sasaran yang telah ditetapkan dan adanya keterkaitan antara nilai-nilai yang bervariasi.

Wirawan (2015) mengemukakan bahwa "Efektivitas dapat digunakan untuk mengukur suatu kerja organisasi karena efektivitas merupakan kemampuan untuk dapat memilih tujuan yang tepat atau peralatan yang tepat untuk pencapaian tujuan yang telah ditetapkan. Dengan kata lain, pelaksanaan pekerjaan atau program di dalam organisasi dikatakan efektif apabila dapat memilih pekerjaan yang harus dilakukan dengan metoda (cara) yang tepat untuk mencapai tujuan."

Hasil perhitungan menunjukkan bahwa efektivitas penanggulangan HIV/AIDS di Kabupaten Sumedang berada pada kategori cukup baik dengan nilai sebesar 61,95\%. Hasil perhitungan tersebut dapat dilihat pada tabel berikut ini:

Tabel 2

Kategori Hasil Pernilaian Efektivitas Penanggulangan HIV/AIDS

Kabupaen Sumedang

\begin{tabular}{|c|c|c|c|c|}
\hline $\begin{array}{l}\text { No } \\
\text { Item }\end{array}$ & Indikator & $\begin{array}{l}\text { Jumlah } \\
\text { Kumulatif }\end{array}$ & $\begin{array}{l}\text { Persentase } \\
(\%)\end{array}$ & Kriteria \\
\hline 1 & $\begin{array}{l}\text { Adanya kesesuaian antara program kerja dengan hasil } \\
\text { pekerjaan }\end{array}$ & 64 & 67,37 & Cukup Baik \\
\hline 2 & $\begin{array}{l}\text { Hasil pekerjaan yang capai sesuai dengan hasil yang } \\
\text { diharapkan }\end{array}$ & 60 & 63,16 & Cukup Baik \\
\hline 3 & Hasil pekerjaan tepat sasaran & 61 & 64,21 & Cukup Baik \\
\hline 4 & Memiliki tingkat motivasi kerja yang tinggi & 64 & 67,37 & Cukup Baik \\
\hline 5 & Pekerjaan diselesaikan dengan mudah & 56 & 58,95 & Cukup Baik \\
\hline 6 & Pekerjaan diselesaikan dengan rapih & 59 & 62,11 & Cukup Baik \\
\hline 7 & Menyelesaikan pekerjaan dengan teliti & 59 & 62,11 & Cukup Baik \\
\hline 8 & Memeriksa kembali pekerjaan sebelum dilaporkan & 58 & 61,05 & Cukup Baik \\
\hline 9 & Tidak mengalami kesulitan yang berarti dalam bekerja & 56 & 58,95 & Cukup Baik \\
\hline 10 & Mampu melalui hambatan didalam bekerja & 54 & 56,84 & Cukup Baik \\
\hline 11 & Pelaksanaan pekerjaan telah sesuai target & 53 & 55,79 & Cukup Baik \\
\hline 12 & $\begin{array}{lllll}\begin{array}{l}\text { Pemanfaatan } \\
\text { kebutuhan }\end{array} & \text { anggaran } & \text { sesuai } & \text { dengan } & \text { rencana } \\
\end{array}$ & 53 & 55,79 & Cukup Baik \\
\hline 13 & Pekerjaan yang dilakukan sesuai dengan kemampuan & 59 & 62,11 & Cukup Baik \\
\hline 14 & Memiliki target kesalahan kerja yang rendah & 59 & 62,11 & Cukup Baik \\
\hline 15 & Memiliki tingkat kehadiran kerja yang tinggi & 66 & 69,47 & Baik \\
\hline 16 & $\begin{array}{l}\text { Menyelesaikan pekerjaan sesuai dengan waktu yang } \\
\text { ditetapkan }\end{array}$ & 63 & 66,32 & Cukup Baik \\
\hline 17 & Bekerja sesuai tupoksi & 61 & 64,21 & Cukup Baik \\
\hline 18 & Mampu menyelesaikan pekerjaan setiap hari & 49 & 51,58 & $\begin{array}{l}\text { Kurang } \\
\text { Baik }\end{array}$ \\
\hline 19 & Bekerja sesuai jam kerja & 61 & 64,21 & Cukup Baik \\
\hline 20 & Tidak menunda-nunda menyelesaikan pekerjaan & 62 & 65,26 & Cukup Baik \\
\hline \multicolumn{2}{|c|}{ Jumlah } & 1177 & 1238,95 & \\
\hline \multicolumn{2}{|c|}{ Rata-Rata } & & 61,95 & Cukup Baik \\
\hline \multicolumn{5}{|c|}{$\begin{array}{l}\text { Sumber: Penelitian } 2018 \\
\quad \text { Berdasarkan tabel di atas diketahui } \\
\text { bahwa terdapat beberapa indikator efektivitas } \\
\text { pelaksanaan program yang masih belum baik, } \\
\text { seperti pelaksanaan pekerjaan yang belum } \\
\text { sesuai target, pemanfaatan anggaran belum } \\
\text { sesuai dengan kebutuhan, belum mampu }\end{array}$} \\
\hline
\end{tabular}


organisasi tersebut. Efektivitas pelaksanaan program sendiri memiliki pengertian sebagai pengukuran dalam arti tercapainya indikatorindikator yang telah ditentukan, seperti sasaran, sosialisasi, tujuan dan pemantauan program. Jadi apabila indikator-indikator tersebut telah dicapai, baru dapat dikatakan efektif.

Adapun Teknik-teknik pengorganisasian dalam efektivitas menurut Hariandja (2007) dibagi dua macam : a)Teknik-teknik pengorganisasin dengan pendekatan tujuan, yiatu dengan langkah-langkah sebagai berikut: Menganalisa ketidakefektifan organisasi, Merumuskan tujuan, Merumuskan gambaran keadaan sekarang, Mengidentifikasi kemudahan dan hambatan, Mengembangkan serangkaian kegiatan; b)Teknik pengorganisasian dengan pendekatan sistem,sistem ini lebih menekankan pentingnya masukan, proses, dan hasil sebagai lokasi kajian keefektifan organisasi. Teknik ini memerlukan perhatian pada 8 (delapan) komponen yang mempengaruhi efektivias organisasi yaitu : Koordinasi, Struktur, SDM, Pembagian tugas, Hukum/ peraturan, Pemasaran, Informasi, dan Dana.

\section{Pengaruh Koordinasi Terhadap Efektivitas Penanggulangan HIV/AIDS Kabupaten Sumedang}

Koordinasi memiliki korelasi yang positif dan signifikan dengan efektivitas penanggulangan HIV/AIDS di Kabupaten Sumedang. Berdasarkan hasil penelitian diketahui nilai dari hubungan tersebut sebesar 0,687 ( $r_{s}$ hitung), dimana nilai tersebut lebih besar dari nilai $r_{s}$ tabel yaitu 0,475. Dengan hasil korelasi tersebut maka variabel koordinasi dapat mempengaruhi tingkatan efektivitas penanggulangan HIV/AIDS di Kabupaten Sumedang sebesar 47,2\% maka dapat diartikan bahwa koordinasi dapat mempengaruhi efektif atau tidaknya suatu pelaksanaan program.

Keterkaitan antara koordinasi dengan efektivitas dikemukakan oleh Hasibuan (2011) mengemukakanan bahwa "Koordinasi adalah suatu usaha yang sinkron atau teratur untuk menyediakan jumlah dan waktu yang tepat dan mengarahkan pelaksanaan untuk menghasilkan suatu tindakan yang seragam dan harmonis pada sasaran yang telah ditentukan". Hubungan koordinasi dan efektivitas dikemukakan juga oleh Suganda (2002) yaitu "Agar di dalam suatu organisasi atau di dalam administrasi pemerintahan terdapat hasil kerja yang efektif, maka setiap kegiatan manusianya harus terkoordinasi".

Selain itu, sebagaimana dijelaskankan oleh Handoko (2003) bahwa "Koordinasi dalam organisasi mendorong meningkatnya efektivitas sehingga dapat dipastikan hasil kerja pegawai akan tercapai sesuai dengan tujuan organisasi yang telah direncanakan sebelumnya". Sedangkan keterkaitan Koordinasi terhadap efektivitas kerja menurut Sugandha adalah "Di dalam organisasi pemerintahan terdapat hasil kerja yang efektif, maka setiap kegiatan yang dilakukan harus terkoordinasi dengan baik".

Berdasarkan uraian di atas, maka penelliti mengemukakan anggapan dasar sebagai berikut: 1)Koordinasi adalah suatu proses penyatupaduan segala kegiatan dan hubungan dari berbagai bagian atau unit kerja yang berbeda sebagai upaya menuju keselarasan dan kesatuan kerja dalam usaha pencapaian tujuan dan sasaran yang telah ditentukan bersama; serta 2)Efektivitas pelaksanaan program merupakan pengukuran dalam arti tercapainya indikator-indikator yang telah ditentukan, seperti sasaran, sosialisasi, tujuan dan pemantauan program.

Degan demikian dapat dinyatakan bahwa koordinasi dapat mempengaruhi tingkat efektivitas dari suatu program

\section{SIMPULAN}

Berdasarkan hasil penelitian, maka dapat ditarik kesimpulan bahwa terdapat hubungan yang signifikan antara koordinasi dengan efektivitas penanggulangan HIV/AIDS pada Komisi Penanggulangan AIDS Kabupaten Sumedang, hal tersebut terlihat dari nilai $Z_{\text {hitung }}$ lebih besar dari $Z_{\text {tabel, }}$ atau 2,91>1,96. Selain itu, terdapat pula pengaruh Koordinasi terhadap Efektivitas Penanggulanggan HIV/AIDS Kabupaten Sumedang sebesar 47\%.

Dengan demikian dapat dikatakan bahwa efektif atau tidaknya pelaksanaan program penanggulanga AIDS pada Komisi Penanggulangan AIDS Kabupaten Sumedang dapat dipengaruhi oleh koordinasi. Apabila koordinasi berjalan dengan baik maka hasil dari pelaksanaan program tersebut dapat efektif. Begitu pula sebaliknya, apabila koordinasi tidak berjalan dengan baik maka 
hasil dari pelaksanaan program pun tidak akan efektif.

\section{DAFTAR PUSTAKA}

Atmosudirjo, P. (1994). Administrasi dan Manajemen Umum. Jakarta: Ghalia Indonesia

Hamdi, A.C. Wijaya, M. \& Iskandar, S. Pencegahan Penularan HIV/AIDS: Efektivitas Metode KIE "Aku Bangga Aku Tahu (ABAT)". Diunduh di http://media.neliti.com/id/publications/67 886/pencegahan-penularan-hivaidsefektivitas-metode-kie-aku-bangga-akutahu-abat. Tanggal 08 Mei 2017.

Handayaningrat, S. (1996). Pengantar Studi Ilmu Administrasi dan Manajemen. Jakarta: Gunung Agung.

Handoko, T. H. (2003). Manajemen (Edisi 2). Yogyakarta: BPFE.

Hariandja, M.T.E. (2007). Manajemen Sumber Daya Manusia: Pengadaan, Pengembangan, Pengkompensasian, dan Peningkatan Produktivitas Pegawai. Jakarta: Grasindo.

Hasibuan, M.S.P. (2011). Manajemen, Dasar, Pengertian dan Masalah(Edisi Revisi). Jakarta: Bumi Aksara.

Hutahaean, J. (2014). Konsep Sistem Administrasi Negara. Yogyakarta: Deepublish.

Iskandar. (2005). Manajemen Personalia. Jakarta: Ghalia Putri. . (2013). Kapita Selekta Administrasi Negara dan Kebijakansanaan Publik. Bandung: Puspaga.

Kodim, N. \& Hiryani. D. Program HIV/AIDS Untuk Rakyat. Diunduh di http://journal.fkm.ui.ac.id.index.php/kesma s/article/view/136. Tanggal 11 Mei 2017.

Komisi Penanggulangann AIDS Kabupaten Sumedang. (2017). Profil Komisi Penanggulangan AIDS Kabupaten Sumedang. Sumedang.

Komisi Penangulangan AIDS Nasional (KPAN). (2014). Mengenal dan Menaggulangi HIV, AIDS, Infeksi Menular Seksual, dan Narkoba. Jakarta.

Lembaga Administrasi Negara RI. (1998). Sistem Administrasi Negara Republik Indonesia. Jakarta: CV. Haji Mas Agung.

Lestrasi, T.R.P. Kebijakan Pengendalian HIV/AIDS di Denpasar. Diunduh di http://journal.fkm.ui.ac.id.index.php/kesma s/article/view/341. Tanggal 11 Mei 2017.

Mangkunegara, A.P. (2000). Manajemen Sumber Daya Manusia Perusahaan. Bandung. Remaja Rosdakarya.

(2014). Perencanaan dan Pengembangan Sumber Daya Manusia. Bandung: Refika Aditama.

Napitupulu, P. \& Mandiri, T. (2008). Ekologi Administrasi Negara. Bandung: Alumni.
Tika, M.P. (2012). Budaya Organisasi dan Peningkatan Kinerja Perusahaan. Jakarta: Bumi Aksara.

Sarwoto. (1991). Dasar-dasar Organisasi dan Manajemen. Jakarta: Ghalia Indonesia.

Siagian, S.P. (2009). Manajemen Sumber Daya Manusia. Jakarta: Bumi Aksara.

Silalahi, U. (2009). Studi Tentang Ilmu Administrasi, Konsep, Teori dan Dimensi. Bandung: Sinar Baru Algesindo.

Suganda, D. (2002). Koordinasi. Jakarta: Intermedia.

Sugiyono. (2006). Metode Penelitian Administrasi. Bandung: Alfabeta.

STIA Sebelas April Sumedang. (2013). Buku Panduan Penulisan Skripsi. Sumedang: STIA.

Syafiie, dkk. (2010). Ilmu Administrasi Publik. Jakarta: Rineka Cipta.

Syamsi, I. (1994). Pokok-pokok Organisasi dan Manajemen. Jakarta: Rineka Cipta.

Thoha, M. (1997). Perilaku Organisasi, Konsep Dasar dan Aplikasinya. Jakarta: PT. Raya Grafindo Persada.

(2003). Dimensi-dimensi Prima Ilmu Administtrasi Negara. Yogyakarta: UGM.

Westra, P. dkk (1980). Aneka Sari Ilmu Administrasi. Yogyakarta: Balai Pembinaan Akademi Administrasi Negara.

Wirawan. (2015). Evaluasi Kinerja Sumber Daya Manusia. Jakarta: Salemba Empat.

Zatnika, E. (2017). Efektivitas Program Generasi Berencana (GenRe) Pada Bidang Keluarga Berencana Di Dinas Pengendalian Penduduk dan Keluarga Berencana Kabupaten Sumedang. Skripsi. STIA Sebelas April Sumedang. 